\title{
PERILAKU STICKY COST PADA BIAYA PENJUALAN, ADMINISTRASI DAN UMUM \\ (STUDI PADA PERUSAHAAN MANUFAKTUR YANG TERDAFTAR DI BURSA EFEK INDONESIA PERIODE 2009-2012)
}

\author{
Risvia Apriliawati \\ Yeterina Widi Nugrahanti \\ Universitas Kristen Satya Wacana, \\ yeterina.nugrahanti@staff.uksw.edu
}

\begin{abstract}
The objective of this study is to find the indication of sticky cost behavior in Indonesian manufacturing companies during 2009-2012 and prove whether the level of sticky cost influenced by the economic level. The cost stickiness can be indicated by asymetric reaction of costs to changes. The samples of this study are 309 companies. For testing the hypothesis, this study use linear regression method. This study found that selling, general and administrative cost increase 0,117 percent when sales increase 1 percent.Whereas, the sales and selling, general and administrative cost decrease 0,049 percent perl percent decrease in sales. This researc also found that the degree of stickiness increase during macroeconomic growth.
\end{abstract}

Key words: sticky cost, selling, general and administrative costs, macroeconomic growth

\section{PENDAHULUAN}

Perilaku biaya merupakan suatu hal yang berpengaruh dalam menentukan tingkat tinggirendahnya biaya serta pengelolaan sumber daya oleh manajemen. Perilaku biayajuga berhubungan dengan keputusan yang diambil manajer untuk menghadapi ketidakpastian permintaan di masa mendatang. Biaya didefinisikan sebagai manfaat yang diberikan untuk memperoleh barang atau jasa (Cooper \& Kaplan, 1998). Dalam teori tradisional perilaku biaya dibagi menjadi fixed cost dan variable cost. Fixed cost merupakan suatu biaya yang tidak dipengaruhi oleh tinggi atau rendahnya tingkat aktivitas, sedangkan variable cost akan berpengaruh secara proposional pada tiap perubahan tingkat aktivitas (Calleja, 2005). Asumsi yang paling mendasar mengenai perilaku biaya ialah adanya hubungan yang berbanding lurus antara biaya dan volume aktifitas ketika mengalami peningkatan atau penurunan pada penjualan (Anderson et al, 2003). Namun pada kenyataannya terdapat karakter perilaku biaya yang sulit untuk disesuaikan dalam pengelolaan biaya (Cooper \& Kaplan, 1998), sehingga membuat asumsi dasar tersebut menjadi tidak sesuai. Bila komponen fixed cost dalam total biaya lebih besar daripada variable cost maka akan menimbulkan yang disebut dengan perilaku sticky cost (Malcom, 1991). Hal ini terlihat ketika volume penjualan meningkat, biaya akan cenderung menyesuaikan dengan ikut mengalami kenaikan tetapi berbeda saat volume penjualan menurun, biaya cenderung kurang menyesuaikan dengan besaran penurunan atau malah tetap, hal inilah yang disebut sticky cost (Anderson et al. 2003; Subramanyam dan Weidenmier, 2003; 
De Medeiros dan Costa, 2004; Windyastuti dan Biyanto, 2005).

Penelitian mengenai sticky cost yang telah dilakukan membuktikan adanya fenomena sticky cost pada beberapa perusahaan di beberapa negara. De Medeiros dan Costa (2004) melakukan penelitian di Brazil, menyimpulkan terdapat perilaku sticky cost di perusahaan-perusahaan tersebut. Anderson et al. (2003) menemukan indikasi perilaku sticky cost pada perusahaaan di Amerika. Teruya et al. (2010) juga menyimpulkan bahwa terjadi indikasi perilaku sticky cost pada biaya penjualan, administrasi dan umum pada perusahan-perusahan di Jepang yang terdaftar pada Tokyo Stock Exchange dari tahun 19752000 .

Di Indonesia indikasi sticky cost ditunjukkan antara lain oleh penelitian Hidayatullah et al (2011). Penelitiannya menggunakan sampel perusahaan manufaktur BEI periode 2005-2009, ditemukan bahwa biaya penjualan, administrasi dan umum (PA\&U) serta HPP bersifat sticky sehingga berakibat buruk dalam keakuratan peramalan laba. Windyastuti dan Biyanto (2005) juga menemukan adanya indikasi perilaku sticky cost di perusahaan yang terdaftar di BEI. Hasilnya menunjukkan biaya penjualan, administrasi dan umum ketika penjualan bersih mengalami kenaikan lebih besar daripada ketika penjualan bersih mengalami penurunan atau dengan kata lain terjadi perilaku sticky cost.

Weidenmier (2003) menemukan perilaku sticky cost pada perusahaan manufaktur lebih signifikan dibandingkan dengan sticky cost di perusahaan finansial dan jasa di USA. Argilés dan Blandón (2009) menguji indikasi terjadinya perilaku sticky cost pada perusahaan perkebunan di Spanyol dengan mengkategorikan ukuran perusahaan. Hasil penelitian menunjukkan bahwa perkebunan dengan ukuran yang besar cenderung memiliki tingkat sticky cost yang lebih tinggi dibanding perkebunan lain.
Penelitian Argilés dan Blandón (2009) secara tidak langsung menyatakan bahwa lingkungan perusahaan juga menjadi salah satu komponen yang mempengaruhi terjadinya indikasi sticky cost dalam bentuk ukuran perusahaan yang berbeda. Banker dan Chen (2006) mengatakan bahwa sticky cost tidak hanya dipengaruhi oleh variabel spesifik perusahaan tetapi juga oleh tekanan dari lingkungan ekonomi yang akan membentuk presepsi manajemen mengenai cost adjustment. Weidenmier dan Subramanyam (2003), Anderson et al (2004), Porporato and Werbin (2010), menyatakan bahwa business environment, macro economic condition seperti inflasi dan pertumbuhan ekonomi akan mempengaruhi komposisi total biaya dan pertimbangan manajerial berkaitan penggunaan utilisasi.

Penelitian ini dilakukan untuk membuktikan secara empiris penelitian Weidenmier dan Subramanyan (2003), Anderson et al (2003), Windyastuti dan Biyanto (2005), Banker (2006), Porporato and Werbin (2010), Teruya et al (2010), Yasukata (2011), Pervan and Pervan (2012) yang menyatakan bahwa salah satu komponen dari lingkungan luar perusahaan yang berupa pertumbuhan ekonomi mempengaruhi tingkat sticky cost pada suatu perusahaan. Apakah terdapat perilaku sticky cost pada biaya penjualan, administrasi dan umum, serta menguji kondisi dan situasi yang berpengaruh terhadap derajat stickiness dengan menggunakan faktor pertumbuhan ekonomi. Namun penelitian ini dilakukan dengan menggunakan sampel dan periode penelitian yang berbeda. Penulis memilih perusahaan manufaktur dikarenakan dalam penelitian sebelumnya oleh Subramanyam dan Weidenmier (2003) menyimpulkan dalam penelitiannya bahwa sektor manufaktur memiliki tingkat sticky cost yang paling tinggi dibandingkan dengan sektor yang lain. Selain itu perusahaan manufaktur merupakan perusahaan yang mengolah bahan mentah menjadi barang 
jadi, sehingga diperkirakan banyak menggunakan aset tetap yang menimbulkan biaya depresiasi dan komponen biaya yang bersifat fix dan variabel.

Keadaan pertumbuhan ekonomi yang terjadi di Indonesia pada periode amatan yakni tahun 2009-2012 sendiri menunjukkan tingkat perekonomian yang terus mengalami kenaikan (Badan Pusat Statistik, 2012). Di tahun 2009 menunjukkan tingkat perekonomian 4,60\% yang terus mengalami kenaikan di tahun 2010 yakni sebesar $6,10 \%$; tahun 2011 sebesar $6,50 \%$ ; dan tahun 2012 sebesar 6,70\%. Berdasar keadaan itulah peneliti ingin melihat apakah saat perekonomian tumbuh berbanding lurus dengan indikasi sticky cost yang terjadi.

Tujuan penelitian ini adalah untuk membuktikan apakah terdapat perilaku sticky cost pada biaya penjualan, administrasi dan umum di perusahaan sektor manufaktur. Penelitian ini juga ingin membuktikan apakah terdapat pengaruh dari pertumbuhan ekonomi secara makro terhadap perilaku sticky cost pada perusahaan manufaktur. Penelitian ini diharapkan dapat memberikan manfaat sebagai tambahan pengetahuan mengenai perilaku sticky cost, pembelajaran bagi perusahaan khususnya manajer dalam pengambilan keputusan terkait biaya agar memperhatikan perubahan yang terjadi pada kondisi lingkungan perusahaan, dalam hal ini dilihat melalui pengaruh dari pertumbuhan perekonomian yang berubah di tiap tahun.

\section{REVIEW LITERATUR DAN HIPOTESIS}

\section{Sticky Cost}

Perilaku sticky cost muncul sebagai sebuah persoalan ketika sifat biaya yang cenderung mudah berubah jika mengalami kenaikan namun tetap jika mengalami penurunan. Malcom (1991) menemukan bahwa beberapa biaya memang sulit untuk disesuaikan dengan aktivitas produksinya. Biaya ini cenderung sulit untuk menyesuaikan atau melekat karena fixed cost yang tinggi sehingga walaupun aktivitas perusahaan menurun biaya akan sulit untuk mengikuti. Sifat biaya itulah yang menyebabkan biaya dapat dikatakan sticky. Biaya dapat dikatakan sticky jika besaran peningkatan biaya ketika volume aktivitas perusahaan mengalami kenaikan lebih tinggi dibandingkan ketika volume penjualan mengalami penurunan (Cooper dan Kaplan, 1998; Anderson et al, 2003; Subramanyam dan Weidenmier, 2003; Windyastuti dan Biyanto, 2005). Sticky cost timbul karena ketidakseimbangan penyesuaian sumberdaya yaitu lebih lambat dalam proses penyesuaian yang menurun dibanding proses penyesuaian yang meningkat.

Anderson et al. (2003) menyatakan bahwa lambatnya penyesuaian sumber daya akan mengakibatkan ketidakseimbangan dalam pengeluaran biaya terkait naik turunnya volume aktivitas. Lambatnya penyesuaian tersebut dipicu antara lain karena keputusan manajemen yang disengaja dan terus mempertahankan sumber daya yang tidak terpakai pada saat aktivitas mengalami penurunan (Weiss, 2010). Jika manajer tetap mempertahankan sumber daya yang tidak terpakai maka akan menyebabkan biaya cenderung tetap ketika volume penjualan menurun. Ketika penjualan meningkat biaya dapat mengikuti dengan peningkatan secara proposional, tetapi disaat volume penjualan menurun biaya yang seharusnya juga ikut berkurang ternyata tidak mengikuti penurunan atau bahkan tetap.

Yasukata dan Kajiwara (2011) juga menyatakan hal yang sama berkaitan dengan the adjustment delay theory dan the deliberate decision theory dengan kesimpulan yang diambil bahwa biaya menjadi sticky ketika manajer memperkiraan bahwa volume penjualan dimasa depan akan terjadi peningkatan. Manajer akan mengambil keputusan yang disengaja dengan tetap mempertahankan sumber dayanya yang berlebihan dalam jangka pendek sehingga manajer tidak melakukan adjustment cost, 
meskipun penjualan yang terjadi pada periode yang berjalan mengalami penurunan. Hal inilah yang akan menyebabkan terjadinya perilaku sticky cost.

\section{Sticky Cost Pada Biaya Penjualan,Administrasi \& Umum}

Biaya dikatakan sticky ialah ketika besaran kenaikan biaya lebih tinggi saat volume aktifitas meningkat dibanding penurunan biaya pada saat volume aktifitas menurun (Anderson, et al, 2004). Salah satu penyebab adanya sticky cost pada biaya penjualan, administrasi dan umun ditimbulkan karena keputusan yang diambil oleh manajer yang tujuannya untuk memaksimalkan laba namun dipandang tidak efisien dari sisi pemiliknya (Jensen dan Meckling, 1976). Sehingga dimungkinkan manajer akan mempertahankan sumber daya yang tidak terpakai. Menurut Anderson et al (2006), perilaku biaya administrasi dan umum dapat dipelajari dengan menghubungkan aktivitas penjualan karena volume penjualan memiliki pengaruh pada beberapa komponen biaya penjualan, administrasi dan umum. Ketika manajemen memutuskan untuk mempertahankan utilisasi sebenarnya menunda penyesuaian biaya, yang pada akhirnya membiarkan biaya penjualan, administrasi dan umum tetap. Selain itu penjualan bersih mempengaruhi biaya penjualan, administrasi dan umum.

Komponen penyusun biaya penjualan, administrasi dan umum antara lain biaya gaji karyawan kantor, biaya perbaikan dan pemeliharaan asset kantor, dan biaya penyusutan gedung. Ketika pada suatu periode ternyata mengalami penurunan penjualan, perusahaan tidak begitu saja akan menghentikan karyawan kantornya untuk menurunkan biaya gaji. Karena jika nanti terjadi kenaikan penjualan, perusahaan harus kembali merekrut karyawan dan akan menambah biaya penyesuaian akibat pelepasan sumber daya. Contoh lain misalnya jika terjadi peningkatan penjualan, maka biaya pemeliharaan aset akan mengalami kenaikan sebab penggunaan kapasitas aset yang makin sering digunakan. Tetapi jika suatu saat penjualan mengalami penurunan, perusahaan tidak akan langsung menghentikan atau melepas aset begitu saja. Artinya perusahaan akan tetap mengeluarkan biaya pemeliharaan untuk asetnya walau menganggur, sehingga walaupun biaya pemeliharaan asset yang dikeluarkan tidak sebesar ketika saat terjadi peningkatan penjualan, perusahaan akan tetap menanggung fixed cost. Misalnya seperti mesin komputer, laptop, mesin fotocopy, telepon, dan mesin kantor yang dipergunakan dalam aktivitas penjualan (Windyastuti dan Biyanto, 2005). Hal tersebut berakibat meningkatkan indikasi sticky cost. Biaya-biaya tersebut mudah untuk ditambahkan namun sulit untuk dikurangi pada tingkat tertentu.

Penelitian Medeiros dan Costa (2005) menemukan biaya penjualan, administrasi dan umum meningkat 0,5 persen per kenaikan 1 persen penjualan, namun menurun hanya 0,32 persen per penurunan 1 persen penjualan. Windyastuti dan Biyanto (2005) menemukan biaya penjualan, administrasi dan umum turun sebesar 0,08 persen tiap 1 persen penurunan penjualan. Sedangkan bila penjualan naik 1 persen, biaya penjualan, administrasi dan umum mengalami kenaikan 0,68 persen.

Referensi dalam penelitian sticky cost sebelumnya selalu menggunakan dua proksi sebagai tolak ukur yaitu biaya penjualan, administrasi dan umum sebagai proksi biaya dan penjualan bersih sebagai proksi volume penjualan. Variabel tersebut dipilih karena pada biaya penjualan, administrasi dan umum memiliki nilai yang material dan memiliki komponen fix dan komponen variabel maka biaya ini memiliki sifat semi variabel (Anderson et al, 2003). Penjualan bersih dipilih karena volume aktivitas tidak dapat terukur secara langsung. 
Berdasdarkan uraian tersebut, maka hipotesis pertama dapat disusun sebagai berikut:

$\mathrm{H}_{1}$ : Besaran kenaikan biaya penjualan, administrasi dan umum pada saat penjualan bersih naik lebih tinggi dibanding besaran penurunan biaya pada saat penjualan bersih turun.

\section{Variasi Tingkatan Sticky Cost}

Ketika perekonomian mengalami pertumbuhan, manajerakan membuat keputusan yang optimis dengan tetap mempertahankan sumber daya dibandingkan melakukan penyesuaian terhadap aktivitas penjualan yang benar-benar terjadi. Manajer tidak akan mengurangi sumber daya ketika lingkungan perekonomian stabil yang dilihat melalui tingkat perekonomian yang terus mengalami pertumbuhan dari tahun ke tahun, sehingga stickiness akan lebih tinggi. Dikatakan juga bahwa ada perbedaan sticky cost dikarenakan pertumbuhan ekonomi yang terjadi di lingkungan perusahaan (Windyastuti dan Biyanto, 2005). Ketika pertumbuhan tinggi maka akan membuat situasi perusahaan kondusif yang berakibat manajemen akan jauh lebih optimis dalam pengambilan keputusan atas sumber dayanya. Dibandingkan ketika pertumbuhan ekonomi yang rendah manajemen akan lebih berhati-hati dalam perkiraan penjualan di masa yang akan datang karena daya beli masyarakat yang berkurang (Yasukata dan Kajiwara, 2011).

Berdasarkan hal tersebut, maka hipotesis kedua dapat dirumuskan sebagai berikut:

H2 : Peningkatan stickiness pada biaya penjualan, administrasi dan umum akan berbanding lurus dengan tingkat pertumbuhan ekonomi.

\section{METODE PENELITIAN}

\section{Populasi dan Sampel}

Populasi dari penelitian ini adalah perusahaan-perusahaan manufaktur yang terdaftar di Bursa Efek Indonesia (BEI) periode 20092012. Data yang diambil adalah data sekunder yang diperoleh dari website resmi $w w w . i d x$. com. Data yang digunakan dalam penelitian ini adalah biaya penjualan, administrasi dan umum, dan penjualan bersih. Pengambilan sampel dengan metode purposive sampling yaitu dengan kriteria perusahaan yang terdaftar di Bursa Efek Indonesia (BEI) periode 2009-2012 dan biaya penjualan, administrasi dan umum tidak melebihi penjualan bersih.

\section{Metode Analisis}

Penelitian ini menggunakan model perhitungan yang telah dikembangkan oleh Anderson et al. (2003), dan digunakan dalam penelitian Subramanyan dan Weidenmier (2003), Windyastuti dan Biyanto (2005), Hidayatullah et al.(2011) ntuk menemukan indikasi sticky cost pada biaya penjualan, administrasi dan umum. Interaksi antara variabel Decreased Dummy (DECRDUM) mengambil nilai 1 jika pendapatan penjualan menurun antara periode $\mathrm{t}-1$ dan $\mathrm{t}$, dan nilai 0 jika pendapatan penjualan meningkat antara periode t-1 dan t. (Windyastuti dan Biyanto, 2005; Medeiros dan Costa, 2004; Anderson et al., 2006; dan Hidayatullah et al., 2010).

\section{Pengujian Hipotesis 1 :}

$\log \left[P A \& U_{i, t} / P A \& U_{i, t}\right]=\beta_{0}+\beta_{1}\left[\right.$ Sales $_{i, t} /$ Sales $\left._{i, t}\right]+$ $\beta_{2}{ }^{*}$ DECRDUM $_{i, t}{ }^{*} \log \left[\right.$ Sales $_{i, t}$ Sales $\left._{i, t-1}\right]+\varepsilon_{i, t}$

keerangan:

$P A \& U_{i, t}=$ Biaya Penjualan, Administrasi dan Umum perusahaan i pada periode $\mathrm{t}-1$

$P A \& U_{i, t-1} \quad=$ Biaya Penjualan, Administrasi dan Umum perusahaan i pada periode $\mathrm{t}-1$

Sales $_{i, t} \quad=$ Penjualan bersih pada periode $\mathrm{t}$

Sales $_{i, t-1}=$ Penjualan bersih pada periode $\mathrm{t}-1$ $D E C R D U M_{i, t}=$ Variabel Dummy bernilai 1 jika penjulan bersih turun antara periode $\mathrm{t}$ dan $\mathrm{t}-1$, serta 0 jika sebaliknya.

$\varepsilon_{i, t} \quad=$ Residual 
Variabel-variabel dan model diatas diuji dengan menggunakan uji regresi berganda. Jika biaya penjualan, administrasi dan umum adalah sticky, variasi biaya administrasi dan umum dengan penjualan bersih bertambah harus lebih besar dibanding ketika penjualan bersih menurun. Koefisien $\beta$, mengukur presentase kenaikan biaya penjualan, administrasi dan umum akibat kenaikan penjualan bersih sebesar 1 persen, sedangkan penjumlahan koefisien $\beta_{1}+\beta_{2}$ mengukur presentase kenaikan biaya penjualan, administrasi dan umum akibat penurunan penjualan bersih sebesar 1 persen.

Hipotesis 1 mendasarkan pada $\beta_{1}>0$ dan $\beta_{2}<0$, atau jika $\beta_{1}+\beta_{2}<\beta_{1}$, dengan demikian menunjukkan bahwa kenaikan biaya penjualan, administrasi dan umum pada saat penjualan bersih naik lebih tinggi dibandingkan penurunan biaya penjualan, administrasi dan umum pada saat penjualan bersih turun. Ini berarti dapat dikatan biaya penjualan, administrasi dan umum bersifat sticky (Anderson et al. 2003).

\section{Pengujian Hipotesis 2 :}

$\log \left[P A \& U_{i, t} / P A \& U_{i, t}\right]=\beta_{0}+\beta_{1} * \log \left[\right.$ Sales $_{i, t}$ Sales $_{i, t}$ $\left.{ }_{1}\right]+\beta_{2}{ }^{*}$ DECRDUM ${ }_{i, t}{ }^{*} \log \left[\right.$ Sales $_{i, t}$ Sales $\left._{i, t}\right]+\beta_{3}{ }^{*} D E$

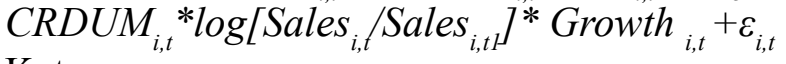

Keterangan:

growth = pertumbuhan ekonomi

Hipotesis 2 dilakukan untuk menguji kondisi dan situasi yang berpengaruh terhadap derajat stickiness. Untuk menguji hipotesis 2, model utama dikembangkan lebih lanjut dengan memasukan faktor besaran presentase pertumbuhan ekonomi. Growth dikatakan berpengaruh jika signifikansi secara statistik dengan nilai $\alpha$ (alpha) sebesar 0,05. Dengan signifikannya variabel-variabel tersebut maka analisis kondisi dan situasi yang mempengaruhi derajat stickiness biaya penjualan, administrasi, dan umum dapat dilakukan.

Growth ditunjukan dengan tingkat pertumbuhan ekonomi pada tahun amatan yakni tahun 2010 sebesar 6,10\%; tahun 2011 sebesar 6,50\% dan tahun 2012 sebesar 6,70\% (Badan Pusat Statistik, 2012). Pengaruh growth terhadap derajat stickiness biaya penjualan, administrasi dan umum terlihat dari $\beta_{3}$ yang bertanda negatif dan signifikan (Pradipta, 2013). Ini berarti bila tingkat perekonomian mengalami pertumbuhan, maka variasi penurunan biaya penjualan, administrasi dan umum akibat penurunan penjualan bersih akan lebih kecil dibandingkan ketika tingkat perekonomian tidak mengalami pertumbuhan.

\section{HASIL PENELITIAN DAN PEMBAHASAN}

\section{Proses Pengambilan Sampel Penelitian}

Data sekunder yang dipilih dan diperoleh berupa laporan keuangan perusahaan tahunan (annual report) perusahaan manufaktur periode 2009-2012 yang telah terdaftar di website resmi Bursa Efek Indonesia. Pemilihan outlier atau data ekstrim pada sampel didasarkan dengan melihat nilai residu ( $Z$ score) dari setiap variabel. Data dikatakan normal jika nilai $Z$ score berada di antara rentang nilai $-2,5>Z<2,5$, dan akan diidentifikai sebagai outlier jika berada di luar rentang nilai tersebut.

\section{Tabel 1}

Hasil Pemilihan Sampel

\begin{tabular}{|l|c|}
\hline \multicolumn{1}{|c|}{ Kriteria Sampel yang Dipilih } & $\begin{array}{c}\text { Jumlah } \\
\text { Data }\end{array}$ \\
\hline Emiten & 138 \\
\hline $\begin{array}{l}\text { Data perusahaan manufaktur yang } \\
\text { terdaftar di BEI tetapi tidak menerbitkan } \\
\text { laporan keuangan tahun 2009-2012 secara } \\
\text { terus menerus }\end{array}$ & $(12)$ \\
\hline $\begin{array}{l}\text { Jumlah biaya penjualan, administrasi } \\
\text { dan umum perusahaan manufaktur yang } \\
\text { melebihi pendapatan penjualan bersih }\end{array}$ & $(9)$ \\
\hline Sampel emiten & 117 \\
\hline Sampel data (2009-2012) & 351 \\
\hline $\begin{array}{l}\text { Outlier Hipotesis 1 } \\
\text { Outlier Hipotesis 2 }\end{array}$ & 50 \\
\hline $\begin{array}{l}\text { Total sampel data hipotesis 1 } \\
\text { Total sampel data hipotesis 2 }\end{array}$ & 301 \\
\hline
\end{tabular}




\section{Statistik Deskriptif}

Tabel 2 menunjukan deskriptif statistik untuk perubahan pada Biaya Penjualan, Administrasi dan Umum di perusahaan manufaktur yang terdaftar di BEI pada tahun 2009-2010, 2010-2011 dan 2011- 2012.

\section{Tabel 2}

Deskriptif Statistik Perusahaan Manufaktur

\begin{tabular}{|c|c|c|c|c|c|}
\hline & $\begin{array}{c}\text { Rata-rata } \\
\text { Dalam (Rp) }\end{array}$ & $\begin{array}{c}\text { Jumlah } \\
\text { Sampel } \\
\text { Mengalami } \\
\text { Penurunan }\end{array}$ & $\begin{array}{c}\% \\
\text { Penurunan } \\
\text { Jumlah } \\
\text { Perusahaan }\end{array}$ & $\begin{array}{c}\text { Jumlah } \\
\text { Sampel } \\
\text { Mengalami } \\
\text { Peningkatan }\end{array}$ & $\begin{array}{c}\% \\
\text { Kenaikan } \\
\text { Jumlah } \\
\text { Perusahaan }\end{array}$ \\
\hline $\begin{array}{l}\text { Perubahan } \\
\text { Biaya } \\
\text { Penjualan, } \\
\text { Administrasi } \\
\text { \& Umum } \\
\text { Tahun } \\
2010 / 2009 \\
\end{array}$ & $\begin{array}{c}\text { Rp. } \\
158.877 .687 .576\end{array}$ & 27 & $23 \%$ & 90 & $77 \%$ \\
\hline $\begin{array}{l}\text { Perubahan } \\
\text { Biaya } \\
\text { Penjualan, } \\
\text { Administrasi } \\
\text { \& Umum } \\
\text { Tahun } \\
2011 / 2010 \\
\end{array}$ & $\begin{array}{l}\text { Rp. } \\
126.705 .085 .894\end{array}$ & 28 & $24 \%$ & 89 & $76 \%$ \\
\hline $\begin{array}{l}\text { Perubahan } \\
\text { Biaya } \\
\text { Penjualan, } \\
\text { Administrasi } \\
\text { \& Umum } \\
\text { Tahun } \\
\text { 2012/2011 } \\
\end{array}$ & $\begin{array}{c}\text { Rp. } \\
186.492 .249 .418\end{array}$ & 21 & $18 \%$ & 96 & $82 \%$ \\
\hline $\begin{array}{l}\text { Perubahan } \\
\text { Penjualan } \\
\text { Tahun } \\
\text { 2010/2009 }\end{array}$ & $\begin{array}{c}\text { Rp. } \\
623.762 .334 .968\end{array}$ & 28 & $24 \%$ & 89 & $76 \%$ \\
\hline $\begin{array}{l}\text { Perubahan } \\
\text { Penjualan } \\
\text { Tahun } \\
2011 / 2010\end{array}$ & $\begin{array}{c}\text { Rp. } \\
1.053 .334 .520 .714\end{array}$ & 16 & $14 \%$ & 101 & $86 \%$ \\
\hline $\begin{array}{l}\text { Perubahan } \\
\text { Penjualan } \\
\text { Tahun } \\
\text { 2012/2011 }\end{array}$ & $\begin{array}{c}\text { Rp. } \\
818.486 .473 .954\end{array}$ & 30 & $26 \%$ & 87 & $74 \%$ \\
\hline
\end{tabular}

Tabel 2 menggambarkan perubahan biaya yang terjadi pada penjualan bersih dan biaya penjualan, administrasi dan umum. Data tersebut menunjukkan dari 117 sampel perusahaan terjadi penurunan dan peningkatan biaya pada perusahaan manufaktur di Indonesia periode 2009-2012. Tahun 2009- 2010 jumlah sampel yang mengalami penurunan biaya penjualan, administrasi dan umum sebanyak 27 perusahaan atau sebesar 23 persen dari keseluruhan total sampel. Kemudian jumlah sampel yang mengalami peningkatan biaya penjualan, administrasi dan umum sebanyak 90 perusahaan atau sebesar 77 persen.

Tahun 2010- 2011 jumlah sampel yang mengalami penurunan biaya penjualan, administrasi dan umum sebanyak 28 perusahaan atau sebesar 24 persen dari keseluruhan total sampel. Kemudian jumlah sampel yang mengalami peningkatan biaya penjualan, administrasi dan umum sebanyak 89 perusahaan atau sebesar 76 persen. Tahun 2011- 2012 jumlah sampel yang mengalami penurunan biaya penjualan, administrasi dan umum sebanyak 21 perusahaan atau sebesar 18 persen dari keseluruhan total sampel. Kemudian jumlah sampel yang mengalami peningkatan biaya penjualan, administrasi dan umum sebanyak 96 perusahaan atau sebesar 82 persen.

\section{Pengujian Hipotesis}

Untuk mengetahui apakah terdapat perilaku sticky cost pada perusahaan manufaktur, terlebih dahulu dilakukan uji asumsi klasik terdiri dari uji multikolinearitas, autokorelasi, heteroskedastisitas dan normalitas. Hasil menunjukan bahwa model lolos untuk semua uji asumsi klasik.

\section{Hasil Pengujian Hipotesis 1}

Hipotesis 1 diuji untuk melihat apakah besaran kenaikan biaya penjualan, administrasi dan umum ketika penjualan bersih naik lebih tinggi dibanding besaran penurunan ketika penjualan bersih turun.

\section{Tabel 3}

Hasil Uji Regresi Biaya Penjualan. Administrasi, dan Umum

\begin{tabular}{|c|c|c|}
\hline \multirow{2}{*}{ Model } & \multicolumn{2}{|c|}{ Unstrandartdized Coefficients } \\
\cline { 2 - 3 } & B & Std. Error \\
\hline Penjualan & 0,117 & 0,044 \\
\hline Periode &,- 068 & 0,072 \\
\hline
\end{tabular}

Tabel 3 menunjukan bahwa, nilai $\beta_{1}$ sebesar 0,117 yang artinya jika penjualan mengalami peningkatan sebesar 1 persen maka biaya penjualan, administrasi dan umum meningkat sebesar 0,117 persen. Kemudian nilai $\beta_{2}$ menunjukan besaran -0,068. Asumsi koefisien $\beta_{1}>$ 0 dan koefisien $\beta_{2}<0$ memenuhi syarat. Sehingga dengan menjumlahkan koefisien $\beta_{1}(0,017)+\beta_{2}$ $(-0,068)$ maka akan diperoleh hasil 0,049 , yang 
artinya jika penjualan menurun sebesar 1 persen maka biaya penjualan, administrasi dan umum hanya mengalami penurunan sebesar 0,049 persen.

Data dari hasil uji diatas mendukung hipotesis 1 yaitu peningkatan biaya penjualan, administrasi dan umum lebih tinggi pada saat penjualan naik dibandingkan penurunan biaya pada saat penjualan menurun. Hal ini mengindikasikan adanya sticky cost pada biaya penjualan, administrasi dan umum pada perusahaan manufaktur di Indonesia, sehingga hipotesis 1 diterima. Hasil uji ini sesuai dengan penelitian oleh Weiss (2010), juga Windyastuti dan Biyanto (2005) bahwa biaya penjualan, administrasi dan umum mengalami sticky sebab komponen yang paling banyak sebagai penyusunnya ialah fixed cost.

Pada tabel 2 terdapat perubahan biaya penjualan, administrasi dan umum yang tidak proposional. Data perubahan penjualan di tahun 2009-2010 hingga 2010-2011 terjadi peningkatan sebesar Rp 429.572.185.746 diikuti perubahan penurunan biaya sebesar Rp 32.172.601.682. Tetapi pada periode 2010-2011 hingga 20112012 terdapat penurunan penjualan sebesar Rp234.848.046.760 diikuti dengan peningkatan biaya sebesar Rp 59.787.163.524. Dari analisis tersebut dapat dimungkinkan telah terjadi indikasi inefisiensi biaya akibat manajer yang kurang mampu menyesuaikan biaya dengan baik atas dasar pergerakan penjualan yang berakibat timbulnya sinyal sticky cost.

Sticky cost pada biaya penjualan, administrasi dan umum terjadi jika manajer memutuskan untuk menahan sumber daya yang tidak terpakai daripada melakukan adjustment cost ketika volume mengalami penurunan, manajer mungkin ragu untuk mengurangi utilization ketika penjualan menurun maka biaya penjualan, administrasi dan umum akan tetap karena tidak segera disesuaikan (Anderson et al, 2003). Selain itu Weiss (2010) menyatakan bahwa biaya penjualan, administrasi dan umum dikatakan sticky jika komponen terbesarnya ialah fixed cost, yang menyebabkan biaya penjualan, administrasi dan umum sulit mengikuti pergerakan penjualan.

Contoh dari data sampel misalnya pada PT. Budi Acid Jaya Tbk, dalam data menunjukan ketika penjualan di tahun 2010 sebesar Rp 2.124.381.000.000, biaya penjualan, administrasi dan umum yang dikeluarkan sebesar $\mathrm{Rp}$ 108.026.000.000. ketika di tahun 2011 penjualan nya mengalami peningkatan menjadi Rp 2.503.984.000.000 atau sebesar 17,86 persen. Sedangkan biaya penjualan, administrasi dan umumnya menjadi Rp 136.812.000.000 atau meningkat sebesar 26,64 persen. Kemudian di tahun 2012 penjualan menunjukan penurunan menjadi Rp 2.295.369.000.000 atau menurun sebesar 8,32 persen. Sedangkan biaya penjualan,administrasi dan umum menjadi Rp 116.189.000.000 atau juga mengalami penurunan sebesar 15,07 persen. Data di atas menunjukan bahwa besaran peningkatan pada biaya penjualan, administrasi dan umum saat penjualan naik akan lebih tinggi dibandingkan dengan ketika biaya penjualan, administrasi dan umum saat penjualan turun.

\section{Hasil Pengujian Hipotesis 2}

\section{Tabel 4}

Hasil Uji Regresi Growth

\begin{tabular}{|l|r|r|r|r|}
\hline \multirow{2}{*}{ Model } & \multicolumn{2}{|c|}{$\begin{array}{c}\text { Unstrandartdized } \\
\text { Coefficients }\end{array}$} & \multirow{2}{*}{ t } & \multirow{2}{*}{ Sig. } \\
\cline { 2 - 3 } & \multicolumn{1}{c|}{ B } & \multicolumn{1}{|c|}{ Std. Error } & & \\
\hline Penjualan & 0,066 & 0,026 & 2.555 & 0.11 \\
\hline Periode & $-0,095$ & 0,04 & -2.357 & 0.19 \\
\hline Growth & $-0,005$ & 0,003 & -2.018 & 0.045 \\
\hline
\end{tabular}

Sumber: hasil olah data

Hipotesis 2 dilakukan untuk menguji kondisi dan situasi yang berpengaruh terhadap derajat stickiness. Growth dikatakan berpengaruh jika secara statistik signifikansinya kurang dari dengan nilai $\alpha$ (alpha) sebesar 0,05. Dari hasil 
uji regresi di atas terlihat bahwa nilai signifikansi menunjukkan $0,045(<0,05)$. Ini berarti growth berpengaruh terhadap tingkat sticky cost pada biaya penjualan, administrasi dan umum. Hasil ini sesuai dengan penelitian Anderson et al (2003) dan Windyastuti dan Biyanto (2005) yang menyatakan bahwa terdapat pengaruh pertumbuhan ekonomi terhadap sticky cost.

Pengaruh growth terhadap derajat stickiness biaya penjualan, administrasi dan umum terlihat dari $\beta_{3}$ yang bertanda negatif dan signifikan. Ini berarti bila tingkat perekonomian mengalami pertumbuhan, maka variasi penurunan biaya penjualan, administrasi dan umum akibat penurunan penjualan bersih akan lebih kecil dibandingkan ketika tingkat perekonomian tidak mengalami pertumbuhan.

Pengaruh growth terhadap sticky cost terlihat ada nilai $\beta_{3}$ yaitu $-0,005$. Sesuai dengan kerangka teoritis yang mendasari koefisien nilai signifikansi $\beta_{3}$ yang negatif dan signifikan. Dari hasil di atas menunjukan bahwa ketika perekonomian mengalami pertumbuhan maka variasi penurunan biaya penjualan, administrasi dan umum akibat penurunan penjualan bersih akan lebih kecil dibandingkan ketika perekonomian yang tidak mengalami kenaikan (Windyastuti dan Biyanto, 2005). Manajer akan berekspetasi lebih tinggi ketika kondisi perekonomi yang terjadi mengalami pertumbuhan. Sebab manajer akan menyimpulkan bahwa penjualan yang akan terjadi di masa mendatang juga mengalami peningkatan seiring dengan perekonomian yang makin berkembang. Sulit bagi manajer untuk menyesuaikan sumber daya walaupun pada kenyataannya penjualan bersih perusahannya mengalami penurunan. Sehingga indikasi sticky cost yang terjadi lebih tinggi. Temuan ini mendukung hipotesis 2 bahwa stickiness pada biaya penjualan, administrasi dan umum akan terlihat lebih besar selama periode dimana perekonomian mengalami pertumbuhan.
Kemudian untuk melihat seberapa besar peningkatan atau penurunan sticky cost pada tiap periode amatan dapat dilihat sebagai berikut:

(i) Tahun 2009-2010

\section{Tabel 5a}

Hasil uji periode 2009-2010

\begin{tabular}{|c|c|c|}
\hline \multirow{2}{*}{ Model } & \multicolumn{2}{|c|}{ Unstrandartdized Coefficients } \\
\cline { 2 - 3 } & $\mathrm{B}$ & Std. Error \\
\hline Penjualan & 0,178 & 0,232 \\
\hline Periode & $-0,107$ & 0,528 \\
\hline
\end{tabular}

Sumber: hasil olah data

Tingkat pertumbuhan ekonomi di tahun 2010 menunjukan 6,10 persen. Dan dari hasil pengujian sticky cost tahun 2009-2010 jika penjualan mengalami peningkatan sebesar 1 persen maka biaya penjualan, administrasi dan umum meningkat sebesar 0,178 persen. Kemudian jika penjualan menurun sebesar 1 persen maka biaya penjualan, administrasi dan umum hanya mengalami penurunan sebesar 0,071 persen $(0.178-0,107)$.

(ii) Tahun 2010-2011

Tabel 5b

Hasil uji periode 2010-2011

\begin{tabular}{|c|c|c|}
\hline \multirow{2}{*}{ Model } & \multicolumn{2}{|c|}{ Unstrandartdized Coefficients } \\
\cline { 2 - 3 } & B & Std. Error \\
\hline Penjualan & 0,478 & 0,173 \\
\hline Periode & $-0,208$ & 0,636 \\
\hline
\end{tabular}

Sumber: hasil olah data

Tingkat pertumbuhan ekonomi di tahun 2011 menunjukan 6,50 persen. Dan dari hasil pengujian sticky cost tahun 2010-2011 jika penjualan mengalami peningkatan sebesar 1 persen maka biaya penjualan, administrasi dan umum meningkat sebesar 0,478 persen. Kemudian jika penjualan menurun sebesar 1 persen maka biaya penjualan, administrasi dan umum hanya mengalami penurunan sebesar 0,27 persen $(0,478-0,208)$. 
(iii) Tahun 2011-2012

Tabel 5c

Hasil uji periode 2011-2012

\begin{tabular}{|c|c|c|}
\hline \multirow{2}{*}{ Model } & \multicolumn{2}{|c|}{ Unstrandartdized Coefficients } \\
\cline { 2 - 3 } & $\mathrm{B}$ & Std. Error \\
\hline Penjualan & 0,471 & 0,169 \\
\hline Periode & $-0,397$ & 0,210 \\
\hline
\end{tabular}

Sumber: hasil olah data

Tingkat pertumbuhan ekonomi di tahun 2012 menunjukan 6,70 persen. Dan dari hasil pengujian sticky cost tahun 2012-2011 jika penjualan mengalami peningkatan sebesar 1 persen maka biaya penjualan, administrasi dan umum meningkat sebesar 0,471 persen. Jika penjualan menurun sebesar 1 persen maka biaya penjualan, administrasi dan umum hanya mengalami penurunan sebesar 0,074 persen (0,471-0,397).

Tujuan dari analisis yang dipecah ke per periode adalah untuk melihat bagaimana suatu perbedaan kondisi dan situasi dari ekternal perusahaan, dalam penelitian ini berupa tingkat pertumbuhan ekonomi yang terjadi pada periode tertentu berdampak pada sticky cost. Selain itu untuk meneliti sticky cost dibutuhkan data periode sebelum dan sesudah amatan.

Setelah melakukan uji untuk tiap periode amatan terbukti bahwa terjadi peningkatan sticky cost yang berbeda. Penemuan ini sesuai dengan penemuan Windyastuti (2010), jika perekonomian mengalami pertumbuhan maka stickiness pada biaya penjualan, administrasi dan umum akan terlihat semakin besar selama periode dimana makro ekonomi tumbuh.

\section{Tabel 6}

Tingkatan Variasi Sticky Cost Periode 2009-2012

\begin{tabular}{|c|c|c|c|c|c|}
\hline No. & $\begin{array}{l}\text { Periode } \\
\text { Amatan }\end{array}$ & $\begin{array}{c}\text { Tingkat } \\
\text { Pertumbuhan } \\
\text { Ekonomi (\%) }\end{array}$ & $\begin{array}{c}\text { Kenaikan } \\
\text { Besaran Biaya } \\
1 \% \text { Penjualan }\end{array}$ & $\begin{array}{c}\text { Penurunan } \\
\text { Besaran } \\
\text { Biaya } \\
\text { 1\% Penjualan }\end{array}$ & Selisih \\
\hline 1 & $2009-2010$ & 6,10 & 0,178 & 0,071 & 0,107 \\
\hline 2 & 2010-2011 & 6,50 & 0,478 & 0,27 & 0,208 \\
\hline 3 & 2011-2012 & 6,70 & 0,471 & 0,074 & 0,397 \\
\hline
\end{tabular}

Sumber: hasil olah data
Dari table 6, kolom tingkat pertumbuhan menunjukan tingkat perekonomian yang terjadi di tiap periode amatan. Kolom selanjutnya menunjukan besaran kenaikan dan penurunan sticky cost per periode. Kolom selisih menjelaskan selisih dari respon biaya kenaikan dan penurunan sticky cost atas satu persen perubahan penjualan. Jika persentase di kolom selisih semakin tinggi artinya tingkat sticky cost pada periode tersebut juga tinggi (Pradipta, 2013). Dapat dilihat bahwa perekonomian yang terjadi terus mengalami peningkatan, begitu juga dengan selisih sticky cost yang juga mengalami hal yang sama. Hal ini membuktikan bahwa besarnya sticky cost akan berubah secara positif dengan perubahan tingkat perekonomian yang terjadi di Indonesia.

Jika pertumbuhan ekonomi mengalami peningkatan, maka besarnya sticky cost juga akan meningkat. Sesuai Anderson et al (2003) menyatakan bahwa manajer memiliki peranan penting dalam besarnya biaya dan perubahan respon biaya atas perubahan penjualan/ pendapatan. Ketika perekonomian mengalami kenaikan dimungkinkan manajer akan mempertahankan utilisasinya karena berpikir bahwa penjualan nantinya juga akan mengalami peningkatan di masa datang, yang dapat menimbulkan penyesuaian biaya yang kurang baik atas dasar pergerakan penjualan yang berdampak pada tingginya sticky cost.

\section{KESIMPULAN DAN SARAN}

\section{Kesimpulan}

Dari hasil pengujian hipotesis pertama, ditemukan adanya indikasi perilaku sticky cost pada biaya penjualan, administrasi dan umum pada perusahaan manufaktur di Indonesia periode 2009-2012. Hal ini dibuktikan dengan kenaikan pada biaya penjualan, administrasi dan umum yang lebih tinggi ketika penjualan bersih meningkat dibandingkan dengan penurunan biaya biaya penjualan, administrasi dan umum pada saat penjualan bersih menurun. 
Temuan ini sesuai dengan hasil dari penelitian Anderson et al (2003), Medeiros dan Costa (2005), windyastuti dan Biyanto (2005), Teruya (2010), Hidayatullah et al (2011) yang menyimpulkan bahwa besaran kenaikan biaya penjualan, administrasi dan umum terlihat lebih besar saat terjadi kenaikan penjualan bersih dibandingkan ketika terjadi penurunan aktifitas atau penjualan bersih.

Dari hasil pengujian hipotesis kedua yang telah dilakukan bisa dilihat bahwa pada periode amatan 2009- 2012 pertumbuhan ekonomi terus mengalami peningkatan. Hal tersebut juga diikuti pada besaran stickiness di tiap tahun periode amatan sehingga dapat disimpulkan bahwa besarnya besaran sticky cost dipengaruhi oleh pertumbuhan ekonomi, artinya jika pertumbuhan ekonomi semakin meningkat maka besaran stickiness pada biaya penjualan, administrasi dan umum juga mengalami kenaikan.

\section{Implikasi}

Dari analisis yang telah dilakukan terdapat indikasi sticky cost pada biaya penjualan administrasi dan umum pada perusahaan manufaktur di Indonesia. Karena itu peran dari manajer merupakan salah satu hal yang perlu diperhatikan sebab Anderson et al (2006) menyatakan bahwa ketidakstabilan biaya yang dapat menyebabkan sticky cost adalah sebuah sinyal akibat manajer yang tidak mampu menyesuiakan biaya dengan baik atas dasar pergerakan penjualan. Sehingga di harapkan manajer lebih berhati- hati dalam mengatur strategi untuk mengelola sumber daya perusahaan.

Selain itu dari hasil penelitian yang menunjukkan adanya pengaruh dari pertumbuhan ekonomi di Indonesia yang meningkat seiring peningkatan sticky cost, manajer harus mengambil keputusan untuk menahan sumber daya ketika penjualan menurun atau melakukan penyesuaian dengan segera.

\section{Keterbatasan dan Saran}

Dalam penelitian ini biaya yang dipilih ialah biaya penjualan, biaya administrasi dan umum yang telah banyak dipilih untuk melihat adanya fenomena sticky cost (Anderson et al, 2003; Subramaniam dan Weidenmier, 2003; Windyastuti dan Biyanto, 2005; Hidayahtullah et al, 2010). Pada penelitian selanjutnya mungkin dapat dipilih jenis biaya lain seperti biaya produksi yang terkait langsung dengan kegiatan utama perusahaan untuk diuji apakah sticky atau anti sticky. Selain itu bisa digunakan nilai kurs dan inflasi sebagai variabel faktor eksternal, apakah memiliki pengaruh terhadap besaran sticky cost jika terjadi di perusahaan- perusahaan. Pengujian lebih lanjut dapat dilakukan dengan melihat tingkat perubahan sticky cost per sektor perusahaan.

\section{DAFTAR PUSTAKA}

Anderson, et al., SN., 2003, “Are Selling, General, and Administrative Cost "Sticky"?", Journal of Accounting Research, Vol. 41, No. 1.

Anderson, MC., et al., 2006, "Cost Behavior and Fundamental Analysis of SG\&A Costs", AAA 2007 Management Accounting Section (MAS) Meeting Paper.

Argilés, JM., Blandón, JG., 2009, “Cost Stickiness Revisited: Empirical Application for Farms", Revista Española De Financiación Y Contabilidad, Vol. XXXVIII.

Badan Pusat Statistik. 2012. Data Strategis BPS. Jakarta:BPS.

Balakrishnan, R., et al., 2011, "Cost Structure and Sticky Cost", Working paper, Available at SSRN: http://ssrn.com/ abstract $=1562726$ or http://dx.doi. org/10.2139/ssrn.1562726 
Banker, RD., Chen, L., 2006, "Predicting Earning Using A Model Based On Cost Variability and Cost Stickiness", The Accounting Review Vol. 81, No. 2.

Calleja, Kenneth., Steliaros,M., and Thomas, D.C. (2005). Further Evidence on The Sticky Behaviour of Costs". Cass Business School Research Paper, Working Paper. SSRN

Cannon, JN., 2011, "Determinants of 'Sticky Costs': An Analysis of Cost Behavior Using United States Air Transportation Industry Data", AAA2012 Management Accounting Section (MAS) Meeting Paper. Available at SSRN: http://ssrn. com/abstract $=1895615$ or $\underline{\mathrm{http}} / / / \mathrm{dx}$.doi. org/10.2139/ssrn.1895615

Cooper, R. Dan R. Kaplan, 1998, The Design of Cost Management Systems: Text, Cases, and Readings, Upper Saddle River, NJ: Prentice Hall

De Medeiros, Otavio Ribeiro and Costa, Patricia De Souza, 2004, "Cost Stickiness in Brazilian Firm", Paper presented at the $4^{\text {th }}$ USP Congress of Managerial Control and Accounting, Available at SSRN: http://ssrn.com/abstract $=632365$ or http://dx.doi.org/10.2139/ssrn.632365

Direktorat Riset Ekonomi dan Kebijakan Moneter, 2008, "Integrasi Ekonomi ASEAN dan Prospek Perekonomian Nasional (Outlook Ekonomi Endonesia edisi 2008-2012)", http://www.bi.go.id/ web/en/Publikasi/Kebijakan+Moneter/ Outlook+Ekonomi+Indonesia/

Ghozali, Imam H., 2006, Aplikasi Analisis Multivariate Dengan Program SPSS, Badan Penerbit Undip, Semarang.
Hidayatullah, IJ., et al., 2011, “Analisis Perilaku Sticky Cost dan Pengaruhnya Terhadap Prediksi Laba Menggunakan Model Cost Variability dan Cost Stickiness (CVCS) Pada Emiten Di Bei Untuk Industri Manufaktur", SNA, Available at SNA: sna.akuntansi.unikal.ac.id/ makalah/029-AKPM-45.pdf

Jensen, Michael C.;Meckling, William H.,1976, "Theory of the Firm: Managerial Behaviour, Agency Costs and Ownership Structure", Journal of Financial Economics, Vol. 3, No. 4.

Kama, I.,Weiss, D., 2010, “Do Managers' Deliberate Decisions Induce Sticky Costs?", Available at SSRN: http://ssrn. com/abstract $=1558953$ or http://dx.doi. org $/ 10.2139 /$ ssrn. 1558953

Malcom, Robert E. (1991). Overhead Control Implications of Activity Costing. Accounting Horizons.

Pervan, M., Pervan, I., 2012, “Analysis of Sticky Costs: Croatian Evidence", ISBN, 9.

Porporato, Marcela and Werbin, Eliana Mariela, 2010 "Active Cost Management in Banks: Evidence of Sticky Costs in Argentina, Brazil and Canada", $\boldsymbol{A} \boldsymbol{A} \boldsymbol{A}$ 2011 Management Accounting Section (MAS) Meeting Paper. Available at SSRN: http://ssrn.com/ abstract $=1659228$ or http://dx.doi. org/10.2139/ssrn.1659228

Pradipta, OD, 2014, "Bukti Dan Variasi Tingkatan Perilaku Sticky Cost Pada Perusahaan Yang Terdaftar Di BEI”, Working Paper, Universitas Kristen Satya Wacana Institutional Repository Available at http:/repository.library.uksw.edu/ handle/123456789/ 
Teruya, Jenny., Shimizu, T., and He, D. (2010). Sticky Selling, General, and Administrative Cost Behavior and It's Changes in Japan. Global Journal of Business Research.

Weidenmier, ML., Subramaniam, C., 2003, "Additional Evidence on the Sticky Behavior of Costs". TCU Working Paper. Texas Christian University, Available at SSRN: http://ssrn.com/ abstract $=369941 \quad$ or $\quad$ http://dx.doi. org $/ 10.2139 /$ ssrn.369941

Weis, D., 2010, “Cost Behavior And Analysts' Earnings Forecast". The Accounting Review Vol. 85, No. 4.
Windyastuti, Biyanto, F., 2005, “Analisis Perilaku Kos: Stickiness Kos Pemasaran, Administrasi \& Umum Pada Penjualan Bersih (Studi Empiris Perusahaan yang Terdaftar di BEJ". SNA VIII, Solo.

Yasukata, K., Kajiwara, T., 2011, “Are 'Sticky Costs' The Result of Deliberate Decision of Managers?", Working paper, Available at SSRN: http://ssrn. com/abstract $=1444746$ or http://dx.doi. org/10.2139/ssrn.1444746 